\title{
Design and Fabrication of Industrial Washing Machine for Heat Treated Metals
}

\author{
C. Sowmya Dhanalakshmi, M. Karthikeyan, S. Kirubakaran, J. Lokeshkumar, D. Parthasarathi
}

\begin{abstract}
The clothes washer is generally utilized in the present day's general public for washing, drying of garments and furthermore for the warmth treatment procedure of metals and materials which has been created in the business these days. The vast majority of the crude materials utilized in the assembling procedure of the clothes washer have significant negative social and natural effects which incorporates mass scale extraction of metals, arrivals of harmful gases during creation and preparing, defilement of land and wellbeing perils causes in people and creatures. Subsequently it is imperative to relieve these impacts while accomplishing the social necessities. It is accepted that offering an assistance to supplant the residential clothes washer would be doable answer for this situation. Low carbon steel is having every single material property that are worthy for some applications which is required to have heat treatment process. Here we are thinking of completely mechanized mechanical utilization heat treated clothes washer for improve flexibility, durability, quality, hardness and rigidity and to remember interior pressure created in the materials.

Keywords: Heat treated, Industrial washing machine, Annealing, Austempering, Hardening, Tempering,
\end{abstract} Blower and Elevator.

\section{INTRODUCTION}

$\mathrm{T}$ o establish quality cleaning of parts, all process variables should be considered, which includes previous processes and soils from previous processes. The subsequent process should also be considered, as residues and soils from the previous operation may not be tolerable. The washer capability and capacity should be understood in terms of the types of soils it is capable of removing. The existing water quality should be taken into account, and water treatment should be considered if necessary (excessive water hardness). The bio stability of the cleaner should be reviewed to avoid the growth of bacteria and fungus and to avoid the use of biocides and fungicides. Finally, the part orientation should be considered including

Revised Manuscript Received on March 16, 2020.

* Correspondence Author

Dr. C. Sowmya Dhanalakshmi*, Associate Professor in the department of mechanical engineering, SNS College of Technology, Coimbatore.

Mr. M. Karthikeyan, pursuing final year B.E. Mechanical Engineering at SNS College of Technology, Coimbatore.

Mr.nS. Kirubhakaran, pursuing final year B.E. Mechanical Engineering at SNS College of Technology, Coimbatore.

Mr. J.Lokeshkumar, pursuing final year B.E. Mechanical Engineering at SNS College of Technology, Coimbatore.

Mr. D. Parthasarathi, pursuing final year B.E. Mechanical Engineering at SNS College of Technology, Coimbatore

(c) The Authors. Published by Blue Eyes Intelligence Engineering and Sciences Publication (BEIESP). This is an open access article under the CC BY-NC-ND license (http://creativecommons.org/licenses/by-nc-nd/4.0/) examination of nesting of parts and the orientation of the spray nozzles with relationship to the parts. Residues remaining after cleaning should also be considered; they should not cause smoking in tempering operations, should not cause flash rusting, and should not result in discoloration of the parts. Clothes washer is a machine that rapidly washes garments, materials and different things. Before the development of the clothes washer, individuals went through hours doing their clothing by hand. A few people absorbed their garments streams and afterward Beat them with rocks to get out the earth. Afterward, individuals scoured their clothing on washing sheets. Additionally individuals on ocean journeys washed their garments by putting the messy clothing in a solid fabric sack, and hurling it over the edge, letting the boat drag the pack for a considerable length of time. This rule of driving water through garments to evacuate earth has been utilized by individuals for a long time and the cutting edge clothes washer can be viewed as a transformative progression of this system. One of the soonest clothes washers which was manual and imitated the movement of the human hand on the washboard, by utilizing a switch to move one bended surface over another and scouring garments between the two ribbed surfaces. This kind of machines were utilized generally until the nineteenth century before the principal electric garments washers, in which an engine pivoted the tub, were acquainted with America toward the start of the twentieth century. The fast headway in innovation has offered ascend to the completely programmed clothes washer which is generally utilized in the present day's general public. These machines have a large number of parts and are greatly modern and easy to understand than the ones utilized at beginning periods of improvement. Anyway so as to accomplish manageability conditions, different factors, for example, crude materials and their sources, life patterns of materials utilized, effectiveness, creation and removal of the item should be viewed as separated from the minor improvement of the innovation .An early Washing Machine utilized in the 1850's.The principle motivation behind this report is to talk about the usefulness, crude materials and their life patterns of the Fisher and Paykel Eco Smart GWL10 clothes washer. Significant worries with these life cycles from a maintainability point of view and conceivable outcomes of expanding effectiveness of the machine are resolved trailed by a conversation on how an assistance could be utilized to supplant the item and predictable favorable circumstances and issues experienced in executing such a plan.

\section{A. Heat Treatment Process}

Heat Treatment system is a chain of operations related to the Heating and Cooling of metals inside the strong state.

Published By:

Blue Eyes Intelligence Engineering \& Sciences Publication

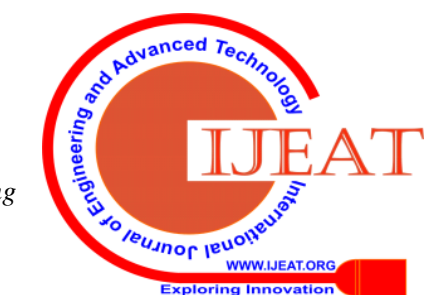




\section{Design and Fabrication of Industrial Washing Machine for Heat Treated Metals}

Its reason is to alternate a mechanical assets or aggregate of mechanical properties so that the steel can be more beneficial, serviceable, and secure for precise cause. By warmness treating, a steel can be made more difficult, stronger, and extra resistant to impact, warmth treatment also can make a metal softer and extra ductile. No one warmness-treating operation can produce all of these characteristics. In truth, a few properties are regularly improved at the price of others. In being hardened, as an instance, a metallic may grow to be brittle.

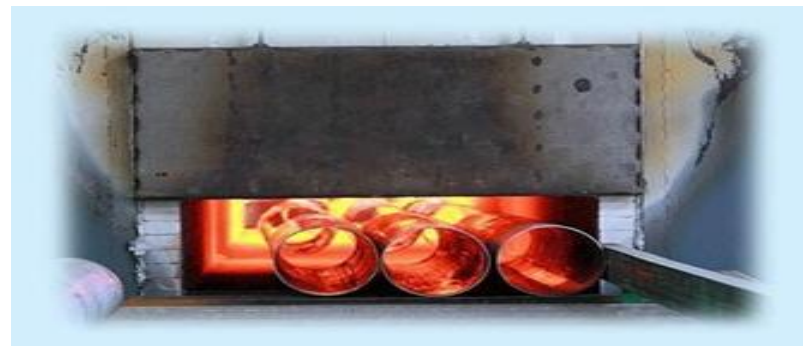

I. B. Types of Heat Treatment Process
1. Annealing
2. Normalizing
3. Quenching
4. Tempering
5. Surface hardening
6. Case hardening
7. Austempering
8. Marquenching
9. Ausforming

\section{A. Annealing}

Annealing is the technique for softening substances or to result in required changes in properties, along with machinability, mechanical or electric houses, or dimensional stability. The annealing method includes heating the steel to or near the important temperature (temperature at which crystalline segment exchange happens) to make it appropriate for fabrication.

\section{B. Normalizing}

It is a type of heat treatment relevant to ferrous metals simplest. It differs from annealing in that the metal is heated to a better temperature and then removed from the furnace for air cooling. The purpose of normalizing is to dispose of the internal stresses triggered by means of warmth treating, welding, casting, forging, forming, or machining.

\section{Quenching}

It is finished to growth the power and wear houses. One of the prerequisites for hardening is enough carbon and alloy content material. To harden by means of quenching, a metal (normally metal or forged iron) have to be heated into the austenitic crystal segment and then speedy cooled.

\section{Tempering}

Tempering is finished by preheating previously quenched or normalized metallic to a temperature below the essential variety, holding, and then cooling to gain the desired mechanical residences. Tempering is used to reduce the brittleness of quenched metal.

\section{E. Surface Hardening}

Surface hardening is the remedy of metallic with the aid of warmness or mechanical way to growth the hardness of the outer surface even as the core remains highly tender. Surface hardened metal is likewise valued for its low and advanced flexibility in production. The oldest surface-hardening technique is carburizing, in which steel is located at a high temperature for numerous hours in a carbonaceous environment. The carbon diffuses into the floor of the metal, rendering it more difficult.

\section{F. Case Hardening}

Case Hardening is the manner of hardening the floor of a steel, often a low carbon metal, with the aid of infusing factors into the material's surface, forming a thin layer of a harder alloy. Case hardening improves the damage resistance of device components without affecting the difficult indoors of the elements.

\section{G. Austempering}

Austempering is warmness remedy this is applied to ferrous metals, most extensively steel and ductile iron. In metallic it produces a bainite microstructure while in forged irons it produces a structure of acicular ferrite and high carbon, stabilized austenite known as ausferrite. It is basically used to enhance mechanical residences or reduce / cast off distortion.

\section{H. Marquenching}

To overcome the regulations of conventional quenching and tempering, Martempering process can be used. Martempering or marquenching allows the transformation of Austenite to Martensite to take location at the identical time at some stage in the structure of the metallic component. Residual stresses advanced throughout martempering are decrease than the ones evolved for the duration of conventional quenching.

\section{Ausforming}

Ausforming also known as Low and High temperature thermomechanical treatments is a method used to increase the hardness and stubbornness of an alloy by simultaneously tempering, rapid cooling, deforming and quenching to change its shape and refine the microstructure.

\section{LITERATURE REVIEW}

French metallurgist Pierre Berthier (1821) the corrosion resistance of iron chromium alloys was first identified in 1821 by French metallurgist Pierre Berthier, who referred to their resistance towards assault by means of some acids and cautioned their use in cutlery. Metallurgists of the nineteenth century have been not able to supply the aggregate of low carbon and high chromium observed in maximum cutting-edge stainless steels, and the excessive-chromium alloys they could produce have been too brittle to be sensible.

French metallurgist Pierre Berthier (1915) an announcement, as it appeared inside the 1915 New York Times, of the development of stainless steel. A few corrosion resistant iron artifacts continue to exist from antiquity. A famous example is the Iron Pillar of Delhi, erected by using order of Kumara Gupta I around AD 400.

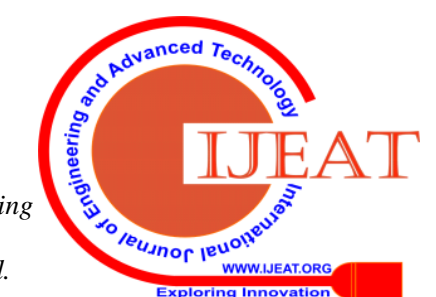


Unlike stainless-steel, however, these artifacts owe their durability not to chromium but to their high phosphorus content material, which, collectively with favorable neighborhood weather conditions, promotes the formation of a solid shielding passivation layer of iron oxides and phosphates, instead of the non-protecting cracked rust layer that develops on maximum ironwork.

Hans Goldschmidt (1890) Within the past due, Germany developed an aluminothermic (thermite) procedure for generating carbon-unfastened chromium. Between 1904 and 1911 several researchers, especially Leon Guillet of France, organized alloys that could nowadays be taken into consideration stainless-steel. Friedrich Krupp Germaniawerft constructed the 366-ton crusing yacht Germania providing a chrome-nickel steel hull in Germany in 1908.In 1911, Philip Monnartz said on the relationship between chromium content material and corrosion resistance.

\section{PROBLEM IDENTIFICATION AND EMPATHY} for:

This program is applicable for approval of manufacturers

$\checkmark$ Heat treated products surface hardened products as referred in the Society's rules and standards.

$\checkmark$ For a description of standard requirements, conditions and approaches related to the approval, please talk over with DNVGL CP 0346 which will be carried out in combination with this application. The corresponding elegance applications for the particular merchandise shall additionally observe.

Some heat treatment processes may qualify other processes as indicated in App. A. Note that for any other process to be qualified in addition to the tested one, the heat treatment documentation and specifications, see Sec.2, shall be submitted and accepted by the Society.

\section{MATERIALS REQUIRED}

- Shell Material - Bottom tank

- Shell Material - Spray Chamber

- Door \& Elevator

- Fabrication charges

- Elevator rollers

- Elevator Pneumatic Cylinder

- Door Cylinders

- Air control solenoid/FRL etc.,

- Spray Pump -3 HP

- Spray pipe lines- SS 304 Grade

- Spray Nozzles- SS 304

- Water Heater- $2 \mathrm{Kw}$

- Blower -1 HP with duct
- Agitator motor-2 HP

- Agitator shaft \& impeller

- Agitator bearing sets

- Oil skimmer

- Oil skimming wiper pump-0.50HP

- Thermocouple

- Control Panel

\section{COMPONENTS USED \& METHODOLOGY ADOPTED}

\section{A. Outer Casing}

The outer casing is rectangular design fabricated out of 5 mm thick virgin MS plate suitable reinforcement for better support and strength in order to withstand the operating temperature without warpage. The tank is double wall system with an air gap of $60 \mathrm{~mm}$ to minimize the bath temperature loss. The bottom casing has channel base for rigidity.

\section{B. Door System}

The front door assembly consist of simple MS fabricated with pneumatic operated system. The door will be leakage arrest system during spray. The door will be lifted and lowered by a suitable reputed make pneumatic cylinder. The cylinder operating system will consist of FLR units and directional control valves and manual ON/OFF switch.

\section{Elevator system}

The elevator consist rollers made up of mild steel and gun metal bushings on both end along with sprockets for gear drive. External gear box is mounted for draining the rollers Vis extended shaft and gear mechanism. There is a forward \& reverse gear drive push buttons fixed on the left front of the machine. The entire elevator is operated by pneumatic cylinders. Manual up/down push buttons are given in the panel board.

\section{Heaters}

The alkali heating system consist of 6 nos immersion type heaters which is placed vertically from the surface of the bottom tank. So that the maintenance is easier.

\section{E. Hot Air Balloon}

There will be an hot air blow system consist of heater bank duly insulated by ceramic wool and duct fabricated using mild steel with fin system to adjust air velocity inside the chamber The system is placed in the top of the washing machine. The hot air temperature can be maintained required level by temperature controller.

\section{F. Control Panel}

Control panel is provided with required switch gear systems like main contractor, isolators, and fuses, relays, ON/OFF switches, indicating lamps and push buttons for operation. 3 number ammeter will be provided to see the amps in 3 phases. 1 number voltmeter will be provided with selector switch for RYB phases.

Published By:

Blue Eyes Intelligence Engineering \& Sciences Publication 


\section{Design and Fabrication of Industrial Washing Machine for Heat Treated Metals}

\section{G. Level Indicator}

There is a level indicator located on the top of the bottom tank (right).This is operated by float type and proximity sensor is provided to sense the lower level of the liquid.

The upper most level is controlled automatically by over flow pipe provided. Hence the liquid cannot go up further.

\section{H. Water Drains}

The drain pipe is fixed at the lowest level of the tank. Almost all the water can be drained out .There is an over flow pipe line is provided just $100 \mathrm{~mm}$ below the elevator level. Hence the water over filling is avoided by automatic over flow.

\section{Oil Skimmer}

Oil skimmer is provided on the right side of the bottom tank upper plate. The skimmer is driven by AC motor with geared drive at constant speed .Stainless Steel AISI 304 Grade skimmer belt is rotated and Teflon oil scraper is provided to wipe off the oils which is in the belt surface.

\section{J. Door Safety}

A safety pin system and hole is provided on the both the Door guides. The pin is tied with a chain link. When any maintenance work taking place, operator must insert this 2 pins in the hole given. So that the door cannot be lowered.

\section{K. Auto System}

The salient feature of this washing machine is the auto washing system. There will be a provision of auto/manual option. The auto mode operation will enable the dunking, spray washing and hot air drying. There will be a 3 digital timers provided to set the required timing for each stage. Once the auto washing is completed, alarm starts. Operator has to acknowledge the alarm and can unload the charge. The timers are mounted inside the panel board for safety purpose.

\section{RESULT}

After analysing all the list of limitations and problems in the current heat treatment washing machine model the following were determined to have a significant effect on the washing machine model accuracy, heat loss due to door operations, thermal gradients inside the washing machine, washing machine deterioration over time. The heat loss in the washing machine due to door operation is a problem more significant in continuous washing than batch washing. With several experimentation and modelling we can develop new model to incorporate in the washing machine model to account this loss. The thermal gradients present inside the washing machine is a complex phenomenon, it is caused due to several factors like skimmer and thermocouple locations, the washing machine construction, etc., and it is also unique to every washing machine. Washing machine wear phenomenon can be modelled by conducting calibration experiments with virtual load and the parameters reverse calculated. These are the development proposed for the improvement of the heat treatment washing machine model.

\section{CONCLUSION}

From the various outcomes obtained in the course of the venture work it is able to be concluded that the mechanical properties vary relying upon the numerous warmness remedy approaches. Hence depending upon the properties and applications required we should move for a appropriate heat remedy approaches. When ductility is the handiest criteria tempering at excessive temperature for 2 hours offers the first-class end result among all tempering experiments however it's far absolutely the hardness of the low carbon metal this is favored than we need to pass for low temperature tempering for 1 hour or so. However if electricity is also preferred at the side of hardness, this need to no longer be finished. It is seen that annealing causes a exceptional increase in \% elongation (ductility). It may be really seen evaluating all the heat treatment techniques, ideal Combination of UTS, Yield Strength, \% Elongation in addition to hardness can be Obtained thru austempering simplest. We hope through our research and analysis we have designed or at least help clarify the design concept of a automated heat treatment washing machine. Hopefully in the near future, such helpful tools became a common addition to all the countries and industries who have a basic domain in the manufacturing and production process.

\section{REFERENCES}

1. Sedricks A.J., (1996) Corrosion of stainless steels, 2nd Edition, Wileyinter science, New York.

2. R. D. Moser, Ph.D., Thesis on "High-Strength Stainless Steels for Corrosion Mitigation in Pre stressed Concrete: Development and Evaluation," Ph.D. dissertation, School of Civil and Material Science in 2011, BIB CODE: 2011PhDT...275M

3. ASM INTERNATIONAL, A textbook on "Electronic Materials Handbook", Volume 4, 1992

4. ASM INTERNATIONAL, Handbook committee, Heat Treating, Volume 4,Materials Park,OH,1991.

5. ZAKI AHMAD, $1^{\text {st }}$ Aug 2006, Principles of Corrosion Engineering and Corrosion Control, $1^{\text {st }}$ Edition, Butterworth-Heinemasnn, Pages 672.

6. S.L.Kakani, Amit Kakani, A textbook on "New Age International on Material Science", 656 pages.

7. CALLISTER (W.D, 2007), Materials Science and Engineering an Introduction (7 Edition), John Wiley \& Sons, New York

8. Funk AC. The Heat Treatment of the stainless steel. Angle orthod 1951 jul; 21(3):129-38.

9. MARS G.FONTANA, A text book on "Corrosion Engineering" Third Edition, New York: McGraw-Hill, 1986

10. H.K.D.H Bhadeshia, A text book on "Steels microstructure and properties" by 3rd edition. (pg 55-78)

11. Carbon and Alloy Steels (an ASM Specialty handbook) Edition J.R.Davis, 1996, ASM International. (OSU: TA479.C37 1996, ISBN 087170-557-5)

12. Vijayendra Singh 2014 Third Edition, Heat treatment of steels, Heat Treatment of Steels (pg. no 450-459)

\section{AUTHORS PROFILE}

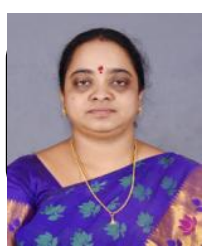

Dr. C. Sowmya Dhanalakshmi is currently working as Associate Professor in the department of mechanical engineering, SNS College of Technology, Coimbatore. She is having a total experience of 14 years in engineering college teaching and years of experience in research. Her areas of interest are Material Science, Industrial Engineering, Biomass and Environmental Science.

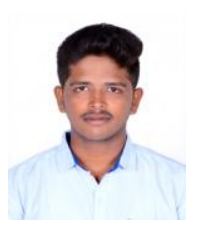

Mr. M. Karthikeyan is currently pursuing his final year B.E. Mechanical Engineering at SNS College of Technology, Coimbatore. He will be awarded his B.E. Degree during the month of May 2020. He is placed in Sakthi Auto Components, Tirupur as Quality Engineer. His areas of interest are materials, quality and maintenance engineering. 


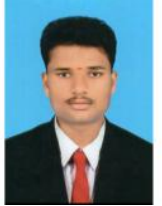

Mr.nS. Kirubhakaran is currently pursuing his final year B.E. Mechanical Engineering at SNS College of Technology, Coimbatore. He will be awarded his B.E. Degree during the month of May 2020. He is placed in Sakthi Auto Components, Tirupur as Quality Engineer. His areas of interest design, NDT and quality.

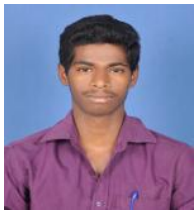

Mr. J.Lokeshkumar is currently pursuing his final year B.E. Mechanical Engineering at SNS College of Technology, Coimbatore. He will be awarded his B.E. Degree during the month of May 2020. His areas of interest are production and manufacturing.

Mr. D. Parthasarathi is currently pursuing his final year B.E. Mechanical Engineering at SNS College of Technology, Coimbatore. He will be awarded his B.E. Degree during the month of May 2020. He is currently working as maintenance engineer in Windcare Pvt. Ltd., Karnataka. His areas of interest are design, quality and production. 